\title{
CYP3A5*3 Allele
}

National Cancer Institute

\section{Source}

National Cancer Institute. CYP3A5*3 Allele. NCI Thesaurus. Code C46021.

Human CYP3A5*3 allele is located in the vicinity of $7 q 21.1$ and is approximately $32 \mathrm{~kb}$ in length. This allele, a variant form of the human CYP3A5 wild-type allele, encodes cytochrome $\mathrm{P} 4503 \mathrm{~A} 5 * 3$ protein. The CYP3A5*3 allele exhibits a clinically-relevant SNP ( . $6986 \mathrm{~A}>\mathrm{G}$ ) in intron 3 that results in a splicing defect and premature stop at 102 amino acids. This alteration severely decreases the enzymatic activity of the cytochrome P450 $3 A 5 * 3$ protein. 